\title{
Availability of Ground-Water Data for California, Water Year 2005
}

\section{INTRODUCTION}

The U.S. Geological Survey, Water Resources, in cooperation with Federal, State, and local agencies, obtains a large amount of data pertaining to the groundwater resources of California each water year (October 1-September 30). These data constitute a valuable database for developing an improved understanding of the water resources of the State.

This Fact Sheet serves as an index to ground-water data for water year 2005. The 2-page report contains a map of California showing the number of wells (by county) with available waterlevel and water-quality data for water year 2005 (fig. 2) and instructions for obtaining this and other ground-water information contained in the databases of the U.S. Geological Survey, California Water Science Center.

From 1985 to 1993, data were published in the annual report "Water Resources Data for California, Volume 5. Ground-Water Data"; prior to 1985, the data were published in U.S. Geological Survey Water-Supply Papers.

\section{HYDROLOGIC CONDITIONS}

Because the geography and geology of California are so complex, ground-water conditions are difficult to summarize. Ground-water levels are affected by short- and long-term climatic conditions and also by ground-water withdrawals, irrigation returns, and other factors.

\section{DATA COLLECTION}

\section{WATER-LEVEL MEASUREMENTS}

Measurements of water levels are made in many types of wells under varying conditions, but they are made using standard methods and equipment to ensure that these measurements are consistently accurate and reliable. All water levels in the California database are given in feet with reference to landsurface datum.

\section{WATER-OUALITY MEASUREMENTS}

The quality of ground water ordinarily changes slowly; therefore, a single annual sampling usually is sufficient to define ground-water quality in most settings. If the quality of ground water is likely to change rapidly because of special circumstances, more frequent sampling may be done to identify the nature of the change.

\section{WELL-NUMBERING SYSTEM}

Wells and springs in California are assigned numbers according to their location in the rectangular system for the subdivision of public land. For example, in the number 005S012E22P001M (fig. 1), the first four characters indicate the township (T. 5 S.), and the next four characters indicate the range (R.12 E.); the two digits following the range indicate the section (sec. 22); and the letter following the section indicates the 40 -acre subdivision of the section. Within each 40-acre subdivision, the wells are numbered serially, as indicated by the last three digits. The final letter indicates the baseline and meridian designation as follows: H, Humboldt; M, Mount Diablo; $\mathrm{S}$, San Bernardino. This 15-digit number is called the Local Number or State Well Number.

\section{DATA AVAILABILITY}

Current and historical data may be accessed directly through the USGS National Water Information Website (NWISWeb) at:

\section{http://waterdata.usgs.gov/}

For more information on how to obtain data, contact:
Tom Haltom, 916-278-3100
(tchaltom@usgs.gov)
Julia Huff, 619-225-6123
(jahuff@usgs.gov).

or

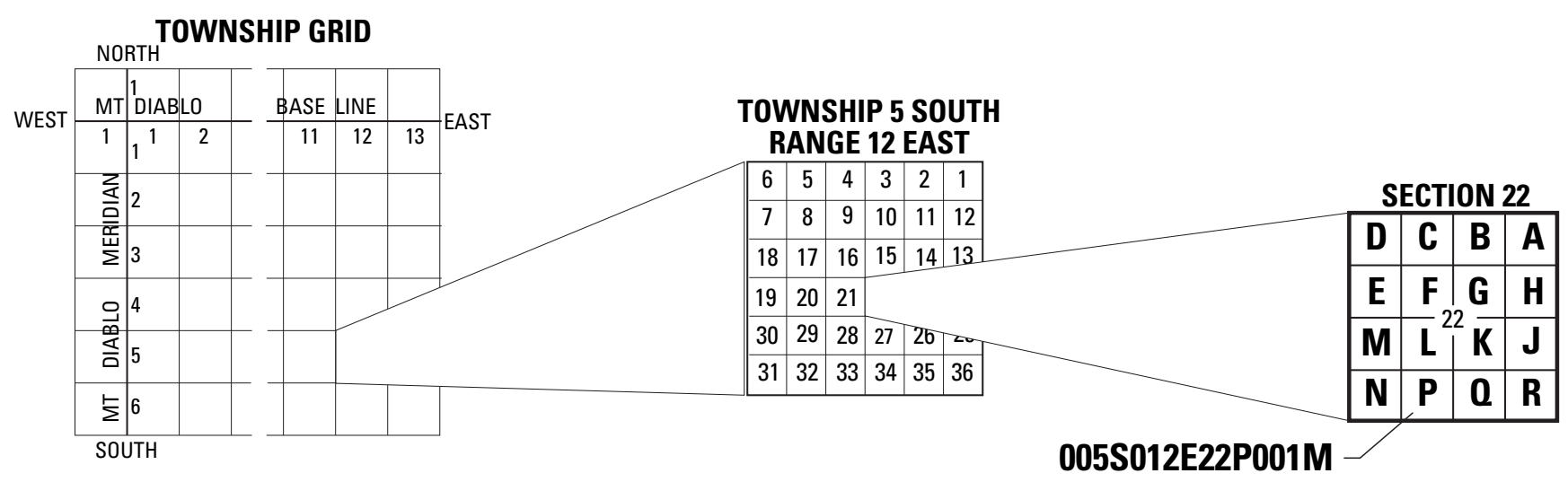

Figure 1. Well-numbering system. 


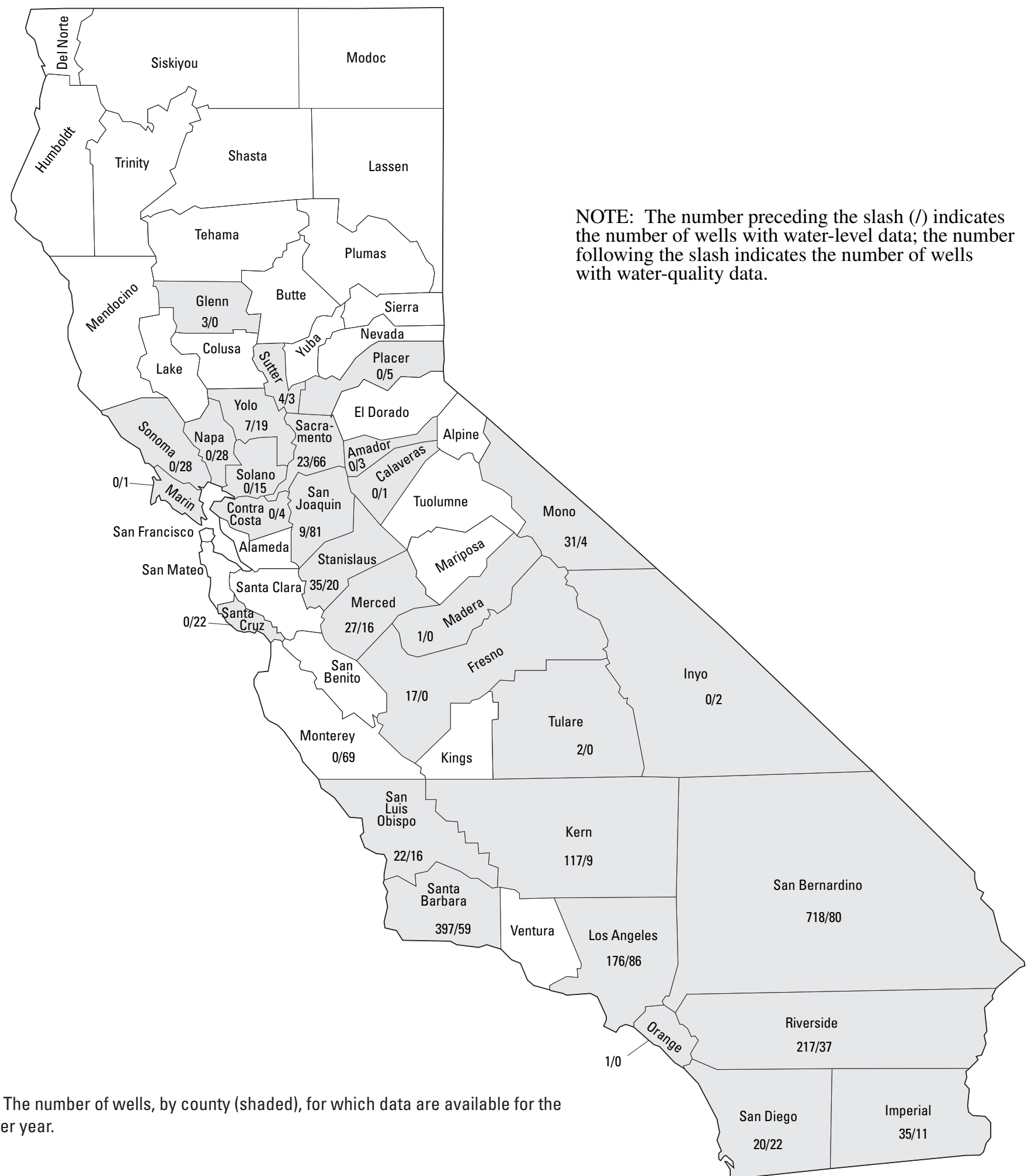

For more information on ground water in California please contact:

Access this fact sheet and other U.S. Geological Survey California

Julia A. Huff (jahuff@usgs.gov) water resources information at:

Technical Information Specialist

U.S. Geological Survey California Water Science Center

San Diego Projects Office

http://ca.water.usgs.gov

4165 Spruance Road, Suite 200

San Diego, CA 92101 